\title{
PENGHIMPUNAN DANA PADA PT. PEGADAIAN CABANG ULAK KARANG PADANG
}

\author{
Tio Omega Syafputra, Elva Dona \\ Akademi Keuangan dan Perbankan Padang
}

\begin{abstract}
ABSTRAK
Tujuan dari penelitian ini untuk mengetahui penghimpunan dana Pada PT. Pegadaian (PERSERO) cabang Ulak Karang Padang. Data yang digunakan dalam penelitian ini adalah mewawancarai langsung pihak-pihak yang berkepentingan dalam hal ini adalah perusahaan yang terkait. Adapun teknik pemgumpulan data yaitu dengan studi lapangan dan studi perpustakaan. Metode penelitian ini yaitu dengan menggunakan teknik wawancara dan teknik kepustakaan. Dimana teknik wawancara ini melakukan wawancara atau peninjauan langsung ke objek penilitian yang dipilih untuk meneliti hasil data sekunder, sedangkan teknik kepustakaan yaitu dengan cara mempelajari bukubuku bacaan, laporan-laporan dan publikasi yang berhubungan dengan objek penelitian. Hasil dari penilitian ini adalah Untuk mengetahui penghimpunan dana pada PT Pegadaian, dan sebagai alat untuk membandingkan antara teori yang di dapatkan diperkuliahan dengan pratek kerja lapangan dan Memberikan pemahaman kepada pembaca mengenai proses penghimpunan dana pada PT Pegadain Cabang Ulak Karang Padang.
\end{abstract}

Kata Kunci: Penghimpun Dana

\section{PENDAHULUAN}

Dalam kegiatan sehari-hari, uang selalu saja dibutuhkan untuk membeli atau membayar berbagai keperluan. Dan yang menjadi masalah terkadang kebutuhan yang ingin dibeli tidak dapat dicukupi dengan uang yang dimilikinya. Kalau sudah demikian, mau tidak mau kita mengurangi untuk membeli berbagai keperluan yang dianggap tidak penting, namun untuk keperluan yang sangat penting terpaksa harus dipenuhi dengan berbagai cara seperti meminjam dari berbagai sumber dana yang ada.

Pegadaian sebagai satu-satunya perusahaan yang menyelenggarakan bisnis gadai dan sarana pendanaan alternatif telah ada sejak lama dan banyak dikenal masyarakat Indonesia, terutama dikota kecil. Selama ini pegadaian selalu identik dengan kesusahan dan kesengsaraan, orang yang datang biasanya berpenampilan lusuh dengan wajah tertekan, tetapi hal itu kini semua berubah. Pegadaian telah berubah diri dengan membangun citra baru, cukup membawa agunan, seseorang terbuka peluang untuk mendapatkan pinjaman sesuai dengan nilai taksiran barang tersebut, agunan dapat berbentuk apa saja asalkan berupa benda bergerak dan bernilai ekonomis. Disamping itu pemohon juga perlu menyerahkan surat atau bukti kepemilikan dan identitas diri, selain itu, kini porum pegadaian banyak menawarkan produk lain selain hanya gadai tradisional. 
Pegadaiaan menyediakan pinjaman uang dengan jaminan barang berharga, meminjam uang kepegadaian bukan saja prosedurnya mudah dan cepat, tetapi biaya yang dibebankan juga lebih ringan. Hal ini dilakukan sesuai dengan salah satu tujuan dari pegadaian, dalam pemberian pinjaman kepada masyarakat dengan motto "mengatasi masalah tanpa masalah".

Hal tersebut berbeda dengan meminjam uang dibank, yang membutuhkan prosedur yang rumit, dan waktu yang relatif lama, persyaratan administrasi juga sulit dipenuhi, Seperti dokumen harus lengkap, jaminan harus barang tertentu, karena tidak semua barang bisa dijadikan jaminan di bank.

Pihak pegadaian juga tidak menanyakan untuk apa meminjam uang, hal ini tentu bertolak belakang dengan pihak perbankan yang menanyakan terlebih dahulu untuk apa uang dipinjam sebelum mengabulkan pinjaman kepada nasabah. Sanksi yang diberikan juga ringan, karena apabila tidak dapat melunasi maka barang akan dilelang untuk menutupi kekurangan pinjaman yang telah diperolehnya.

Seiring berkembangnya waktu, saat ini pegadaian tidak hanya melayani kredit gadai saja, tetapi juga jasa keuangan lain, seperti kredit berbasis fidusia, pembiayaan investasi emas, dan jasa finansial lainnya, Selain itu, Perum Pegadaian sudah bukan monopoli sebagai lembaga keuangan bukan bank di Indonesia yang menggunakan prinsip hukum gadai, Banyak perusahaan swasta yang memberikan layanan gadai sehingga terdapat unsur subyektif yang menjadi Perbedaan antara Pegadaian BUMN dengan pegadaian swasta dalam memberikan pinjaman berdasarkan sifat kredit bisnis pegadaian.

Kegiatan umum yang dilakukan perusahaan pegadaian modern berdasarkan hukum gadai adalah melakukan aktivitas pembiayaan seperti kredit gadai serta menawarkan produk berupa sejumlah jasa nongadai seperti penitipan barang, penaksiran nilai barang, dan gold counter.

Pengertian Kredit gadai adalah fasilitas (kemudahan) pinjaman berdasarkan hukum gadai dengan prosedur sederhana, murah, aman, dan cepat, gadai menurut kitab undang-undang hukum perdata pasal 1150, gadai adalah hak yang diperoleh seorang yang mempunyai piutang atas suatu barang bergerak, barang bergerak tersebut diserahkan kepada orang yang berpiutang oleh seorang yang mempunyai utang atau oleh seorang lain atas nama orang yang mempunyai utang, seseorang yang berutang tersebut memberikan kekuasaan kepada orang berpiutang untuk menggunakan barang bergerak yang telah diserahkan untung melunasi utang apabila pihak yang berutang tidak dapat memenuhi kewajibannya pada saat jatuh tempo.

Jasa penitipan barang ditujukan kepada masyarakat yang merasa keamanan atas barang-barang bergerak miliknya tidak terjamin, terutama bila akan meninggalkan rumahnya dalam jangka waktu yang lama, Atas jasa ini perusahaan pegadaian akan menerima sejumlah uang dari masyarakat sebagai biaya penitipan barang.

Pengertian jasa penaksiran nilai barang adalah jasa pelayanan perusahaan pegadaian kepada masyarakat untuk memberikan informasi 
yang tepat atas nilai barang bergerak milik masyarakat. Pegadaian dapat memberikan penilaian yang tepat karena mereka memiliki petugas yang bersertifikat dalam jasa penaksiran nilai barang, atas jasa ini perusahaan pegadaian menerima sejumlah uang dari masyarakat sebagai biaya penaksiran nilai barang, Gold Counter, yaitu tempat penjualan perhiasan emas di perusahaan pegadaian. Perhiasan-perhiasan emas yang dijual itu berasal dari sebagian simpanan yang tidak diambil kembali oleh pemiliknya setelah jatuh tempo, pegadaian yang memiliki hak gadai atas barang tersebut kemudian menjualnya ke masyarakat.

Perum pegadaian sebagai Lembaga Keuangan tidak di perkenankan untuk menghimpun dana secara langsung dari masyarakat dalam bentuk simpanan (Giro, Deposito, dan Tabungan), melainkan sumber dana yang diperlukan oleh perum pegadaian untuk melakukan kegiatan usahanya berasal dari pinjaman jangka pendek, penerbitan obligasi, modal sendiri.

Dana yang telah berhasil dihimpun kemudian digunakan untuk mendanai kegiatan usaha perum pegadaian, dana tersebut digunakan untuk Uang kas dan dana likuid lain, seperti: kewajiban yang jatuh tempo, penyaluran dana dalam bentuk pembiayaan atas dasar hukum gadai, pembayaran pajak, dan lain-lain. Dan juga digunakan untuk pembelian dan pengadaan berbagai bentuk aktiva tetap dan inventaris berupa tanah dan bangunan serta inventaris ini tidak secara langsung dapat menghasilkan penerimaan bagi perum pegadaian namun sangat penting agar kegiatan usahanya dapat dijalankan dengan baik. Aktiva tetap dan peralatan ini antara lain adalah berupa tanah, kantor atau bangunan, computer, kendaraan, meubel, brankas, dan lain-lain.

Kegiatan operasional perum pegadaian memerlukan dana yang tidak kecil, dana ini antara lain digunakan untuk : gaji pegawai, honor, perawatan peralatan, dan lain-lain pengunaan dana yang utama adalah untuk disalurkan dalam bentuk pembiayaan di atas dasar hukum gadai.

Penyaluran dana ini diharapkan akan dapat menghasilkan keuntungan, meskipun tetap dimungkinkan untuk mendapatkan penerimaan dari bunga yang dibayarkan oleh nasabah.

Penerimaan inilah yang merupakan penerimaan utama bagi Perum Pegadaian dalam menghasilkan keuntungan, meskipun tetap dimungkinkan untuk mendapatkan penerimaan dari sumber yang lain seperti investasi surat berharga dan pelelangan jaminan gadai.

Kelebihan dana (idle fund) yang belum diperlukan untuk mendanai kegiatan operasional maupun belum dapat disalurkan kepada masyarakat, dapat ditanamkan dalam berbagai macam bentuk investasi jangka pendek dan menengah.

Investasi ini dapat menghasilkan penerimaan bagi Perum Pegadaian, namun penerimaan ini bukan merupakan penerimaan utama yang diharapkan oleh perum pegadaian, sebagai contoh perum pegadaian dapat memanfaatkan dananya untuk investasi dibidang property, seperti kantor dan toko, pelaksanaan investasi ini biasanya bekerja sama dengan pihak ketiga seperti pengembang (developer), kontraktor, dan lain-lain. 
Dan sedangkan PT. Pegadaian Cabang Ulak Karang Padang sumber dananya berasal dari PT. Pegadaian Cabang Tarandam dikarenakan PT. Pegadaian Cabang Ulak Karang berstatus sebagai Cabang Pembantu dari PT. Pegadaian Cabang Tarandam.

Berdasarkan uraian tersebut, maka peneliti tertarik untuk mengambil judul tugas akhir "Penghimpunan Dana Pada PT. Pegadaian Cabang Ulak Karang Padang" untuk mengetahui lebih jauh mengenai penghimpunan dana pada PT Pegadaian Cabang Ulak Karang Padang.

\section{Rumusan Masalah}

Berdasarkan latar belakang masalah yang telah diuraiakan di atas, penulis mencoba merumuskan permasalahan yang akan dibahas bagaimana sumber dana PT. Pegadaian Cabang Ulak Karang Padang yang berasal dari pinjaman jangka pendek, penerbitan obligasi, dan modal sendiri, untuk melakukan penghimpunan dana pada PT Pegadaian Cabang Ulak Karang Padang.

\section{Tujuan Penulisan}

Berdasarkan permasalahan di atas, maka tujuan penulisan ini adalah untuk mengetahui asal dari sumber dana PT. Pegadaian Cabang Ulak Karang dalam melakukan penghimpunan dana pada PT Pegadaian Cabang Ulak Karang Padang.

\section{Manfaat penelitian}

Hasil penulisan ini diharapkan dapat memberikan manfaat bagi semua pihak antara lain :

1. Bagi Penulis

Untuk mengetahui penghimpunan dana pada PT Pegadaian, dan sebagai alat untuk membandingkan antara teori yang penulis dapatkan di perkuliahan dengan pratek kerja lapangan.

2. Bagi Pembaca

Memberikan pemahaman kepada pembaca mengenai proses penghimpunan dana pada PT Pegadain Cabang Ulak Karang Padang.

3. Bagi Instansi (PT Pegadaian Cabang Ulak Karang Padang)

Diharapkan dapat digunakan sebagai bahan pertimbangan dalam penghimpunan dana pada PT Pegadaian dalam melakukan kinerja yang lebih baik.

\section{METODE PENELITIAN}

Dalam pengumpulan data dan bahan untuk penelitian ini digunakan metode penelitian pengumpulan data.

a. Teknik Wawancara (Field Research)

Yaitu dengan melakukan wawancara atau peninjauan langsung ke objek penelitian yang dipilih untuk meneliti hasil data sekunder.

b. Teknik Kepustakaan (Library Research)

Yaitu dengan cara mempelajari buku-buku bacaan, laporan-laporan dan publikasi yang berhubungan dengan objek penelitian. 


\section{PEMBAHASAN}

Sumber dana PT. Pegadaian Cabang Ulak Karang Padang berasal dari modal sendiri, pinjaman jangka pendek dari Bank, dan penerbitan obligasi.

\section{Tabel 1}

Sumber Dana PT. Pegadaian Cabang Ulak Karang Padang Tahun 2014-2016

\begin{tabular}{|c|c|c|c|c|c|c|c|}
\hline Thn. & $\begin{array}{c}\text { Pinjaman Jangka } \\
\text { Pendek }\end{array}$ & $\%$ & $\begin{array}{l}\text { Penerbitan } \\
\text { Obligasi }\end{array}$ & $\%$ & Modal Sendiri & $\%$ & $\begin{array}{c}\text { Total } \\
\text { Sumber dana }\end{array}$ \\
\hline 2014 & Rp.12.474.278.448 & \multirow{3}{*}{$\begin{array}{l}5,69 \\
12,50\end{array}$} & Rp. 170.342 .328 & \multirow{3}{*}{$\begin{array}{l}-41,16 \\
20,52\end{array}$} & Rp.528.595.200 & \multirow{3}{*}{$\begin{array}{l}-53,74 \\
-36,22\end{array}$} & Rp.13.173.215.976 \\
\hline 2015 & Rp.13.183.086.779 & & Rp.100.240.459 & & Rp. 244.534 .300 & & Rp.13.527.861.538 \\
\hline 2016 & Rp.14.830.206.024 & & Rp.120.800.256 & & Rp. 155.980 .700 & & Rp.15.173.215.976 \\
\hline
\end{tabular}

Sumber katalog dari Pt. Pegadaian Cabang Ulak Karang.

Pada tabel diatas dapat diuraikan perbandingan persentase penghimpunan dana PT. Pegadaian cabang ulak karang Padang pada tahun 2014-2016 yang sumber dananya yang berasal dari pinjaman jangka pendek, penerbitan obligasi, modal sendiri. Pinjaman jangka pendek dari tahun 2014 ke tahun 2015 mengalami peningkatan sebesar 5,69\%, dan pada tahun 2015 ke 2016 mengalami peningkatan yang cukup besar yaitu sebesar 12,50\%. Hal ini disebabkan karena tingginya tingkat pemberian modal gadai kepada nasabah pt. pegadaian.

Dilihat dari penerbitan obligasi dari tahun 2014 ke tahun 2016 mengalami penurunan $-41,16 \%$ dikarenakan meningkatnya pinjaman jangka pendek ke Bank sebesar 5,69 \% pada tahun 2014 ke 2015, dan sedangkan pada tahun 2015 ke 2016 mengalami peningkatan penerbitan obligasi sebesar $20,52 \%$.

Dan kemudian dilihat dari modal sendiri pt. pegadaian cabang ulak karang pada tahun 2014 ke 2015 mengalami penurunan -53,74 \% dikarenakan banyaknya pinjaman dana dari nasabah pt. pegadaian cabang ulak karang, dan pada tahun 2015 ke 2016 juga mengalami penurunan yang lebih besar sebesar -36,22 \% dikarenakan lebih besarnya pinjaman nasabah pt. pegadaian cabang ulak karang.

Dilihat dari tabel total perkembangan sumber dana pt. pegadaian cabang ulak karang setiap tahunnya mengalami peningkatan, di tahun 2014 total sumber dananya Rp.13.173.215.976 dengan persentase pinjaman jangka pendeknya sebesar $94,70 \%$, penerbitan obligasi $1.30 \%$, dan modal sendiri $4,02 \%$.

Sedangkan di tahun 2015 total sumber dana keseluruhan pt. pegadaian sebesar Rp.13.527.861.538 dengan persentase pinjaman jangka pendek $97,46 \%$, dan penerbitan obligasi $0,75 \%$, sedangkan modal sendiri 1,81 \%.

Dan di tahun 2016 total sumber dana keseluruhan pt. pegadaian cabang ulak karang sebesar Rp.15.106.986.980 dengan persentase pinjaman 
jangka pendek $98,17 \%$, dan penerbitan obligasi sebesar $0,80 \%$, sedangkan persentase modal sendiri di tahun 2016 1,04\%.

Kelebihan dana (idle fund) yang belum diperlukan untuk mendanai kegiatan operasional maupun belum dapat disalurkan kepada masyarakat, dapat ditanamkan dalam berbagai macam bentuk investasi jangka pendek dan menengah. Investasi ini dapat menghasilkan penerimaan bagi Perum Pegadaian, namun penerimaan ini bukan merupakan penerimaan utama yang diharapkan oleh Perum Pegadaian. Sebagai contoh, Perum Pegadaian dapat memanfaatkan dananya untuk investasi dibidang property, seperti kantor dan took. Pelaksanaan investasi ini biasanya bekerja sama dengan pihak ketiga seperti pengembang (developer), kontraktor, dan lain-lain.

Data 1 Gambar Grafik

PT. Pegadaian cabang Ulak Karang Padang Tahun 2014

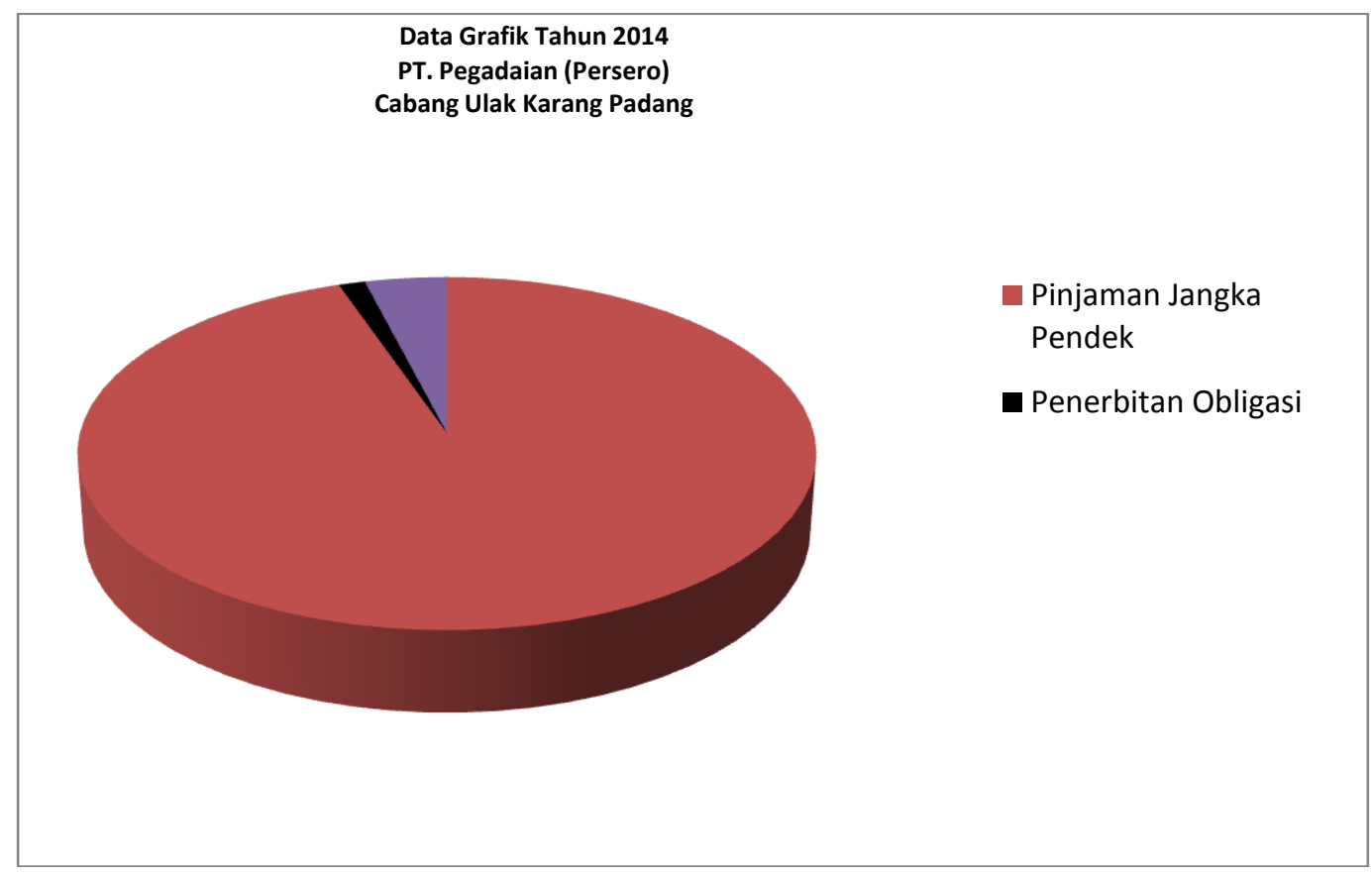

Pada grafik diatas di tahun 2014 dapat diuraikan perbandingan pinjaman jangka pendek, penerbitan obligasi, dan modal sendiri. Pinjaman jangka pendek lebih dominan dibanding penerbitan obligasi dan modal sendiri, dikarenakan pinjaman jangka pendek ke bank telah memenuhi kebutuhan dari nasabah PT. Pegadaian Cabang Ulak Karang Padang. 
Data 2 Gambar Grafik

PT. Pegadaian cabang Ulak Karang Padang Tahun 2015

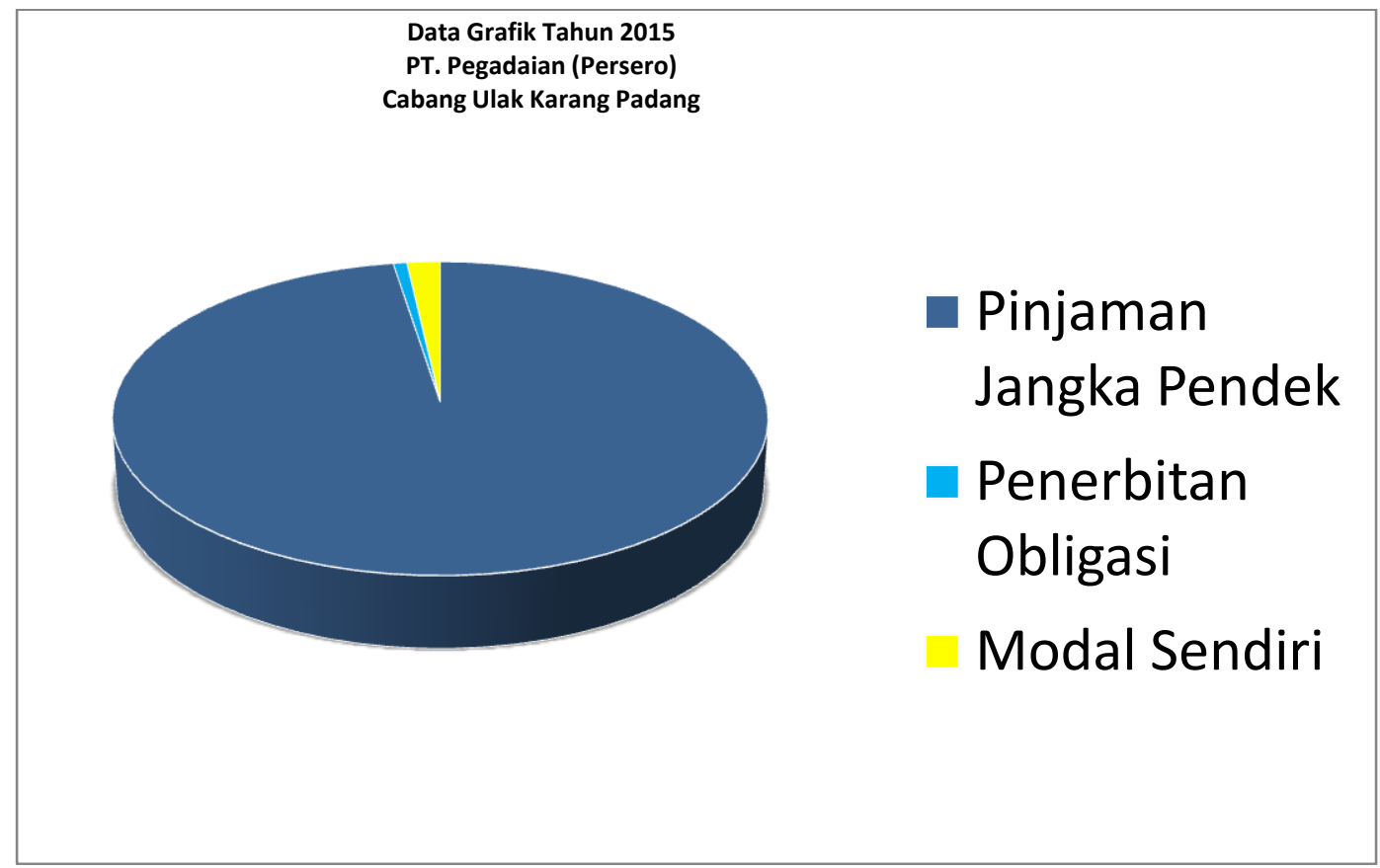

Grafik ditahun 2015 dapat diuraikan perbandingan pinjaman jangka pendek, penerbitan obligasi, dan modal sendiri. Pinjaman jangka pendek lebih dominan dibanding penerbitan obligasi dan modal sendiri, dikarenakan pinjaman jangka pendek ke bank telah memenuhi kebutuhan dari nasabah PT. Pegadaian Cabang Ulak Karang Padang.

\section{Data 3 Gambar Grafik}

PT. Pegadaian cabang Ulak Karang Padang Tahun 2016

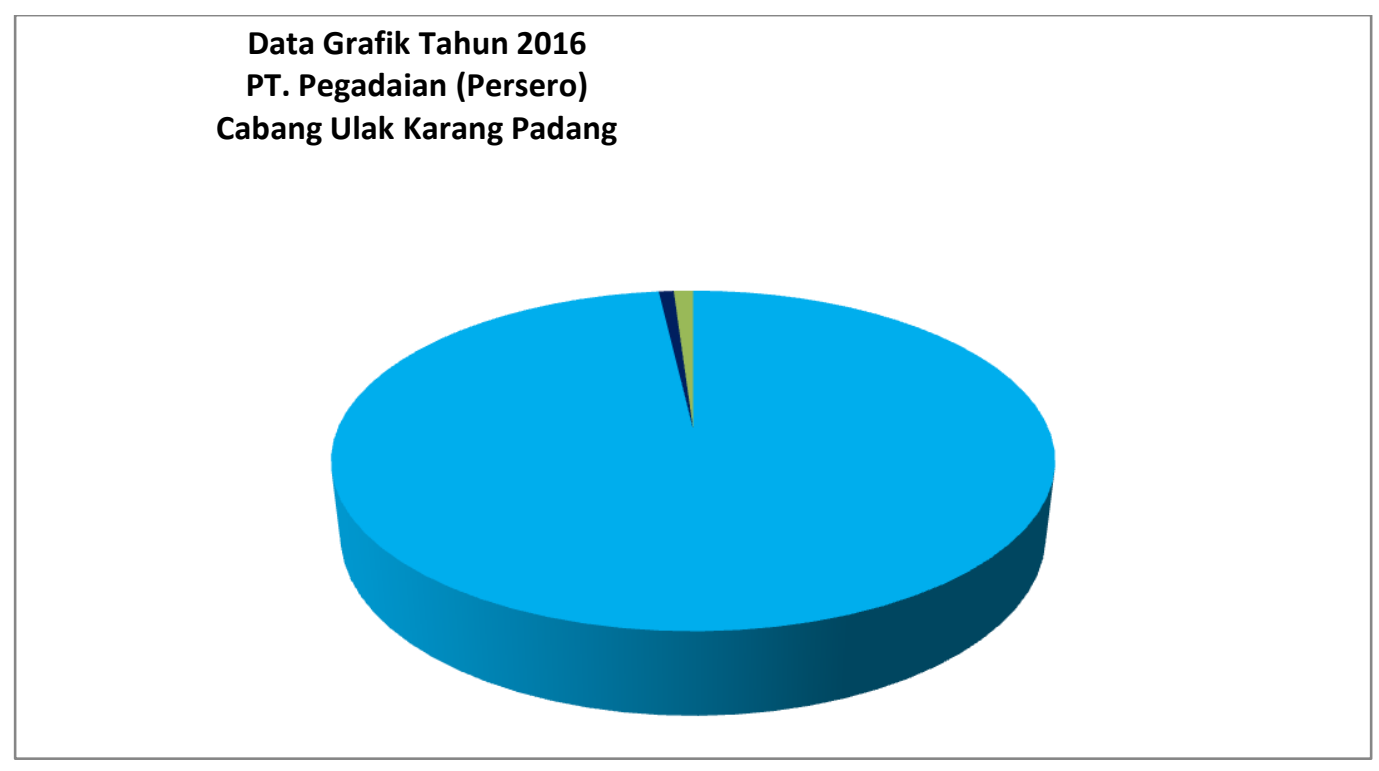


Pada grafik di tahun 2016 diatas dapat diuraikan penghimpunan dana PT. Pegadaian Cabang Ulak Karang Padang, pinjaman jangka pendek lebih lebih dominan pada setiap tahunnya dibanding penerbitan obligasi dan modal sendiri, dikarekan sumber dana dari pinjaman jangka pendek dari bank telah dianggap cukup untuk memenuhi kebutuhan dari nasabah PT. pegadaian, sehingga PT. Pegadaian Cabang Ulak Karang padang mengurangi Penerbitan obligasinya dan modal sendiri yang dianggap telah cukup.

Data 4 Grafik data keseluruhan sumber dana

PT. Pegadaian (persero) cabang ulak karang padang

periode 2014-2016

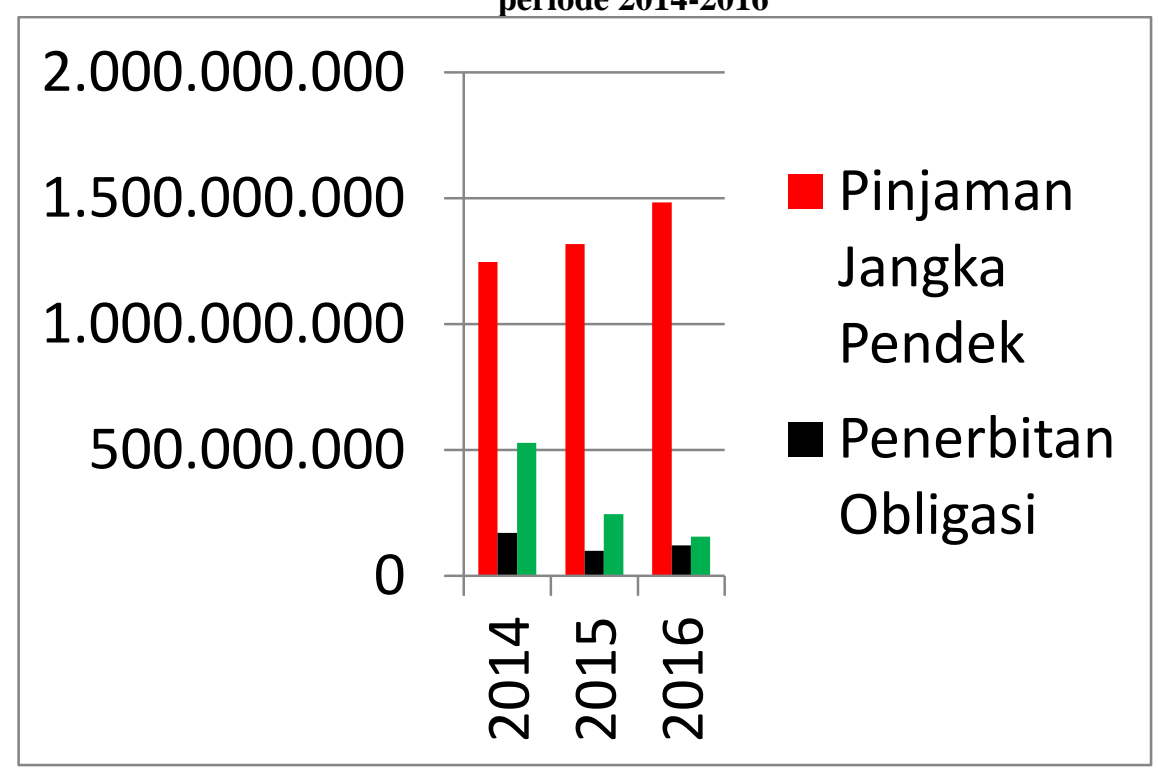

Pada Data Grafik keseluruhan sumber dana PT. Pegadaian Cabang Ulak Padang periode 2014-2016 diatas dapat diuraikan pinjaman jangka pendek PT. Pegadaian Cabang Ulak Karang Padang mengalami kenaikan setiap tahunnya, dikarenakan PT. Pegadaian Cabang Ulak Karang telah menjalin kerja sama dengan Bank BJB, untuk pinjaman jangka pendek ( 6 Bulan ), dan kerja sama itu terjalin setiap tahunnya, dan penerbitan obligasi berbanding terbalik dengan pinjaman jangka pendek, yang mengalami penurunan pada setiap tahunnya, hal ini dengan sengaja dikurangi agar keuangan PT. Pegadaian Cabang Ulak Karang Padang dapat seimbang dengan baik dikarenakan pinjaman jangka pendek dari bank dianggap telah cukup untuk sumber dananya, modal sendiri di PT. Pegadaian Cabang Ulak Karang Padang ditahun 2014 ke 2015 mengalami penurunan dan ditahun 2015 ke 2016 mengalami kenaikan, hal ini dikarenakan sumber dana modal sendiri berasal dari di luar APBN Pemerintah. 


\section{KESIMPULAN}

Setelah melakukan Proses Pembahasan dan Menganalisis Sumber dana

PT. Pegadaian Cabang Ulak Karang Padang Penulis dapat menarik beberapa

Kesimpulan sebagai berikut :.

1. Meningkatnya pinjaman jangka pendek ke Bank setiap tahunnya di tahun 2014 sampai 2016, disebabkan oleh meningkatnya pinjaman gadai oleh masyarakat.

2. Penerbitan obligasi pada tahun 2014 ke 2015 mengalami penurunan dikarenakan tingginya pinjaman jangka pendek ke Bank, dan sedangkan di tahun 2015 ke 2016 mengalami kenaikan penerbitan obligasi.

3. Modal sendiri mengalami penurunan disetiap tahunnya dimulai dari tahun 2014 ke 2016,disebabkan besarnya pinjaman jangka pendek ke Bank, dan meningkatnya pinjaman gadai ke pt. pegadaian cabang ulak karang.

4. Sumber dana pt. pegadaian cabang ulak karang setiap tahunnya mengalami peningkatan, di tahun 2014 dengan persentase pinjaman jangka pendeknya sebesar 94,70 \%, penerbitan obligasi $1.30 \%$, dan modal sendiri $4,02 \%$.

5. Sedangkan di tahun 2015 total dengan persentase pinjaman jangka pendek $97,46 \%$, dan penerbitan obligasi $0,75 \%$, sedangkan modal sendiri $1,81 \%$.

6. Tahun 2016 dengan persentase pinjaman jangka pendek 98,17 \%, dan penerbitan obligasi sebesar $0,80 \%$, sedangkan persentase modal sendiri di tahun $20161,04 \%$.

\section{DAFTAR PUSTAKA}

Annual Report PT Pegadaian (Persero), 2011

Annual Report PT Pegadaian (Persero), 2012

Arifin, I. Z., \& Marlius, D. (2017). Analisis Kinerja Keuangan PT. Pegadaian Cabang Ulak Karang. https://doi.org/10.31227/osf.io/n2peu

Amelia, L., \& Marlius, D. (2018). Pengendalian Kredit Dalam Upaya Menciptakan Bank Yang Sehat Pada PT. Bank Pembangunan Daerah Sumatera Barat Cabang Utama Padang. https://doi.org/10.31227/osf.io/kpc64

Fernandes, Y. D., \& Marlius, D. (2018). Peranan Customer Service Dalam Meningkatkan Pelayanan Kepada Nasabah Pada PT. Bank Pembangunan Daerah Sumatera Barat Cabang Utama Padang. https://doi.org/10.31227/osf.io/wrh3p

Freddy Rangkuti, 1997, Analisa SWOT Teknik Membedah Kasus Bisnis,PT Gramedia Pustaka Utama, Jakarta 
http://bisnis.news.viva.co.id/news/read/241020-emas-ini-paling-diburu-di-brisyariah diakses 17 Juni 2012

Hidayati, R. R., \& Marlius, D. (2018). Aktivitas Promosi Dalam Meningkatkan Dana Pihak Ketiga Pada PT. Bank Perkreditan Rakyat (BPR) Batang Kapas Pesisir Selatan. https://doi.org/10.31227/osf.io/8dgqn

Hunger J. David and wheelen L. Thomas, 2001, manajemen Strategis, Edisi 5 (terjemahan), Andi, Yogyakarta

Marlius, D. Putriani, I. (2019). Kepuasan Nasabah PT. Bank Rakyat Indonesia Unit Tapan Cabang Painan Dilihat dari Kualitas Layanan Customer Service. Jurnal Pundi. Volume 3. No. 2. Hal.111-122. https://doi.org/10.31575/jp.v3i2.151

Mirawati \& Fernos, J. (2019). Peranan Customer Service Dalam Meningkatkan Pelayanan Terhadap Nasabah Pada Bank Nagari Cabang Siteba Padang. https://doi.org/10.31227/osf.io/cq458

Uma Sekaran, 2006, Metodologi Penelitan untuk Bisnis, Edisi I, Salemba Empat Jakarta

Uma Sekaran, 2006, Metodologi Penelitan untuk Bisnis, Edisi II, Salemba Empat Jakarta

Thompson, J, A, Strickland, A. J and Gamble , E.J, 2012, Crafting and Executing Strategy, Seventeenth Edition, McGraw-Hill/Irwin Inc, New York

Rafic Mohammad and Pervaiz K Ahmed, "Using the 7 PS as a Generic Marketing Mix, Marketing Intelligent \& Planning," Vol 13 No 9, 1995 pp 4-15, University Press Limited

Widayati, R. (2019). Aktivitas Pemasaran Produk Simpanan PT. Bank Tabungan Negara (Persero)Tbk Kantor Cabang Padang. https://doi.org/10.17605/OSF.IO/3Z5YC

Yuvendri, R., \& Susanto, R. (2019). Meningkatkan Mutu Pelayanan Dalam Usaha Menghimpun Dana Masyarakat (Tabungan) Pada PT. Bank Perkreditan Rakyat Prima Mulia Anugrah Cabang Padang. https://doi.org/10.31219/osf.io/6prcd 